Tér és Társadalom 18. évf. 2004/1. 73-91. p.

\title{
A RÉGIÓ MINT DISZKURZÍV TERMÉK ${ }^{1}$
}

\author{
(The Region as a Discursive Construct)
}

\author{
VARRÓ KRISZTINA
}

Kulcsszavak:

tér térfogalom térértelmezés nyelv diskurzus régió

A diszkurziv megközelítés terén a kilencvenes évektöl kezdve igazi „boom” figyelhetö meg, nem utolsósorban a területi kérdésekkel foglalkozó szakirodalomban is. Ez a nyelvi közlést elótérbe állitó nézöpont a térfogalmakat mint az emberi kommunikáció nélkülözhetetlen elemeit és termékeit fogja fel, melyek maguk is a valóságot alakítják. A szerzö tárgyalja ezek jellegzetességeit, illetve bemutatja, hogyan tekinthetünk a térstruktúrák létrejöttére mint a térröl való beszéd eredményére, s ez milyen kérdéseket vet fel. Mindezt, ahol lehet, a régiók, illetve azok hazai kialakulásával, kialakitásával kapcsolatos példákkal teszi, mely most a térröl való beszéd egyik leggyakrabban felbukkanó tárgya.

\section{Bevezetés}

Curry $(1996,24)$ szerint ,...telítődve vagyunk olyan tárgyakkal és szavakkal, amelyek meghatározzák, hogy miként gondolkodjunk és beszéljünk a térrỏl. Ez az, ami a tér kérdését oly komplexszé teszi." Ezen idézet második mondatának az a része, mely a tér kérdésének komplexitására utal, közhelyszámba megy, már csak azért is, mert valójában minden felmerülö kérdésnek van a térre vonatkozó dimenziója. A kijelentés érdekessége abban áll, hogy ezt a térrel kapcsolatos tárgyak és szavak sokaságával magyarázza, melyek befolyásolják, hogy hogyan gondolkodunk és beszéliunk a térről. A szavak, pontosabban a nyelv előtérbe állítása korántsem újkeletủ a térrel kiemelten foglalkozó tudományterületeken (mint például a társadalomföldrajzban, területfejlesztésben, vagy a területpolitika elemzésében), de az 1990-es évektől még markánsabban jelenik meg az erre irányuló figyelem. Erre utalnak az olyan elnevezések, mint kommunikáció-elméleti megközelítés (Miggelbrink 2002), illetve a szinte paradigmatikus váltást jelzó kommunikatív, diszkurzív (Salet-Faludi 2000), vagy argumentatív fordulat kifejezések (Hajer 2000).

A hazai szakirodalomban egyelöre azonban még nem érezhetỏ a „,kommunikatív fordulat" szele. Bár egyes tanulmányokban történik utalás arra, hogy a fennálló területi ,rend" diszkurzív párbeszéd eredménye (Pfeil 2003, 201), de eddig csekély érdeklődés mutatkozott ezen aspektus behatóbb vizsgálatára. A ritka példák közé tartoznak például Faragó (2001; 2003a) elméleti jellegủ írásai, melyek a habermasi és foucault-i diskurzusfogalmakat tárgyalják, illetve Ocskay (2002) szintén foucault-i ihletésủ cikke, melyben a szerző a szubszidiaritást mint a lokális diskurzusok felhatalmazását értelmezi egy határ menti kisrégió szerveződésének esettanulmánya alapján. 
De mit is értsünk a „diskurzus” szó alatt? A foucault-i „A diskurzus rendje” (Foucault 1991) címủ elöadás magyar fordítója utal a francia discours, illetve az angol discourse szó pontos magyar fordításának nehézségére, minthogy az hol elöadást, hol beszédet, hol közlést, illetve szöveget jelent. Követve a fordítói gyakorlatot a tanulmány írásakor az idegen nyelvü irodalom feldolgozása során ezt következetesen diskurzus-nak fordítottam.

\section{A térröl való diskurzus}

A régióról való diskurzus szorosan kapcsolható a térről való diskurzushoz, ezért mindenképpen fontos ez utóbbiról is szót ejteni. A tér és a térbeliség kérdése az egész filozófiai gondolkodáson végigvonul, ennek kimerítő áttekintése nem lehet e cikk feladata. Ezért itt csak rövid és szelektív áttekintés következik a térértelmezést illető föbb kérdésekröl. A mindennapi életben magától értetődőnek tünik az abszolút, tartályként mindent magában foglaló tér képzete, illetve az abban lévő tárgyak egymáshoz való viszonyának leírásakor az euklideszi geometria fogalmainak használata. Ez az absztrakt térképzet azonban maga is emberi konstrukció (Smith 1993; Faragó 2003a), mely sikerrel totalizálta a térröl való beszédet. Ezt hangsúlyozza Lefebvre (1991) is A tér megalkotása címủ munkájában, mely címből már kitünik, hogy Lefebvre a térre mint társadalmi produktumra tekint. Az ö olvasatában a homogén, semleges és áttetsző tér „,csupán” a tér reprezentációja, mégpedig a modern kapitalista társadalmakban a legbefolyásosabb. A tér társadalmi termelésének általa kidolgozott koncepciojában a térbeli viszonyok mind anyagi, mind gondolati aspektusaival foglalkozik, három pillérre építve. A materiális térbeli gyakorlatok, mint egy út építése, észlelhető (perçu) eredménnyel járnak. A közigazgatási régiók kijelölésének eredménye konceptualizált tér, melyet az ember gondol ki (conçu). A harmadik, megélt tér (vécu) pedig az egyes térhasználó individuumok által elképzelt tér, mely rátelepszik a fizikai térre, és annak objektumait ruházza fel szimbolikus jelentéssel.

Az üres tér tehát csupán elviekben létezik, azt az ember tölti meg tartalommal. Ez már megjelenik Kantnál is, aki szerint (Kant 1981, 49-54) a tér és az idő szemléleteink szubjektív feltételei, amelyek nem tapasztalatból származnak, hanem ezt egyáltalán lehetővé teszik. A tér tehát külső érzékünk tiszta a priori szemléleti formája. Másrészt: ,„...a dolgokról csak azt ismerjük meg, a priori, amit magunk képzelünk beléjük" (Kant 1981, 13-14). Störig (1997, 554) szerint így valójában Kant a konstruktivizmus ősatyja, mivel azt állítja, hogy a valóság nem „kívül” található, hanem megismerö apparátusunk építi fel.

Az ember tehát térszemléletének megfelelően alakuló térkapcsolataival és azok objektivációival hozza létre a térstruktúrákat (Faragó 2003a, 21). Ezeket az objektivációkat azonban azután hajlamos magától értetődőnek, vagy Weichart $(1999,76)$ szavaival „a valóság önálló, ontológikus struktúrájának” tekinteni, még ha persze ennek nines is mindig tudatában. Valójában ezek ontológiailag nem megalapozottak, evidenciájuk csupán abból adódik, hogy az észlelés és kommunikáció köznapi beszédben mélyen horgonyt vert elemei (Weichart 1999, 77). A köznapi, térről való 
beszédben elkerülhetetlen és egyben szükségszerủ a redukcionizmus, hisz a térbeliségre vonatkozó fogalmak célja éppen a komplex valóság leképezése, struktúrált leírása (Miggelbrink 2002, 13; 158). Ebböl a szempontból a térkoncepciók eszközök, amelyek a valóság észlelt elemeihez jelentést társítanak, azokat megkülönböztetik egymástól. Céljuk az emberi cselekvés irányítása, összehangolása.

\section{A nyelv szerepe}

Mindez egyúttal a nyelvre mint a közlésben nélkülözhetetlen elemre hívja fel a figyelmet. Az, hogy mi is pontosan a nyelv szerepe, a valóságot tükörként visszaadó eszköz, vagy maga is a valóság formálója, szintén a filozófiai gondolkodás egyik központi kérdése. Illetve nem volt mindig az: Descartes és Kant szerint a magányosan reflektáló, minden nyelvhasználat elött álló, interakcióba nem bonyolódott egyén képes érvényes ismereteket szerezni, vagyis helyes fogalmakat kialakítani a valóság tárgyairól éppúgy, mint önmagáról (Felkai 2001, 10). A valóság megismerésében tehát nem tulajdonítanak szerepet a nyelvnek. Később, a felvilágosodás nyomán a pozitivista álláspont nyer teret, mely csupán a tapasztalatot ismeri el a valóság megismerési forrásaként. A kizárólag gondolkodásra alapozott, vagyis a priori lényegi törvényeket már nem tartja többé elfogadhatónak, $\mathrm{s}$ azok átadják helyüket a törvényhipotéziseknek, melyek helyessége megfigyeléssel és kísérlettel vizsgálható felül (Fürst 1993). A pozitivizmus számára a nyelv bár nélkülözhetetlen, de semleges eszköz, mellyel ezek a törvényhipotézisek megfogalmazhatók. Annak tárgyalása, hogy miért és hogyan irányult a filozófia figyelme a nyelvre, illetve hogyan szorult egyre inkább háttérbe ez a pozitivista nézőpont, messze meghaladja e cikk kereteit. A szemléletváltás lényege a nyelvapriori hangsúlyozásában van, vagyis hogy a jelnek transzcendentális elsőbbséget tulajdonít a jelentéssel szemben, illetve, hogy a jelentés azonosságát a jelentési szabályok alkalmazásának interszubjektív gyakorlatától teszi függővé. A paradigmaváltást jól kifejezik Wittgenstein $(1989,70)$ következő megállapításai: „Nyelvem határai a világom határait jelentik.” Illetve: (Wittgenstein 1998, 42) „Az esetek nagy részében - ha nem is minden esetben -, amikor a jelentés szót használjuk, a szót így magyarázzuk: egy szó jelentése - használata a nyelvben."

\section{A térbeliséggel kapcsolatos fogalmak születése}

Visszatérve a térbeliségre vonatkozó fogalmak köznapi használatára, a wittgenstein-i megállapítást a következőképp értelmezhetjük: az egymással való kommunikáció során a térbeliségre vonatkozó kijelentések valójában kommunikatívan eszközölt megkülönböztetések. Például két szomszéd közös megegyezéssel egy határvonallal megkülönbözteti egyikük telkét a másiktól. A „határ” szó valóságtartalma, logikus volta valójában érdektelen; szerepe, hogy a két szomszéd cselekvéseit koordinálja. 
Itt tünik hasznosnak Searle beszédaktus-elméletének (a beszédaktust tekinti a nyelv alapegységének) megemlítése, mely a nyelvre mint az emberi társas életet koordináló elemre is tekint, $\mathrm{s}$ nem csupán mint a fizikai valóságot reprezentáló eszközre. Searle (2000) szintén a nyelvapriorira épít: állítása szerint a legegyszerübb gondolatok kivételével az embernek szüksége van valamilyen nyelvre, hogy elgondolhassa a gondolatot. Kitart egyes, általa alapértelmezett pozícióknak nevezett a priori igazságok léte mellett, és álláspontja szerint a tények a nyelvtől tökéletesen függetlenül léteznek. Megkülönbözteti a világ megfigyelötöl, vagyis embertöl független (pl. erő, tömeg, gravitáció) és a töle függő (pl. kés, szék, angol mondat) sajátosságait. Előbbire utal nála az eredendő, utóbbira az eredeztetett intencionalitás elnevezés. Minden nyelvi jelentés eredeztetett intencionalitás, hiszen az, hogy valamit miért úgy nevezünk, ahogy, az az embertöl függ. Például egy folyó objektív létmóddal rendelkezik, létezése semmilyen tekintetben nem függ attól, hogy megéli-e valamilyen szubjektum. Mivel mibenléte nem attól függ, hogy így nevezzük, léte mint tény nem nyelvi természetủ. A valóság leírására a rendelkezésünkre álló fogalmakban tehát nincs semmi szükségszerü. A Searle által intézményinek nevezett tények azonban nyelvi természetüek: ilyen például a házasság, a tulajdon, a pénz vagy akár egy régió; ezeket az ember hozza létre a nyelv segítségével. Az intézményi valóságban tehát a nyelvet nem pusztán a tények leírására használjuk, hanem azzal tényeket is létrehozunk. Azokat a kijelentéseket, amelyek tényeket létrehoznak, performatívnak nevezi. Ilyen például annak kijelentése, hogy egy folyó két törzs vadászterületének határa. Amint ezt a két törzsfönök egyhangúlag kijelentette, a folyó egyben határfolyó. Csupán a nyelv (melyröl az egyszerűség kedveért feltételezzük, hogy mindkét törzs sajátja) segítségével megváltozott az intézményi valóság. A folyó csak az ember által neki tulajdonított jelentés által lett határ, igaz, e funkcióját fizikai sajátosságai (mély, és/vagy széles, híd nincs felette, ezért az átkelés rajta nehézkes) miatt kapta. Tegyük fel, hogy több híd is létesül a folyó felett, esetleg leapad annak vize, tehát nem lenne akadálya a vadászok átkelésének. Bár ez esetben a fizikai sajátosságok már nem teszik egyértelmủen alkalmassá a határ szerepének betöltésére, mégis e szerep kollektív elfogadása elegendő hozzá. Az intézményi valóság megkonstruálásához tehát a nyelv nem elég, szükség van még a társas együttmüködést lehetővé tevő kollektív intencionalitásra, a feladat kijelölésére, illetve a cselekvést szabályozó létesítő szabályokra. A nyelv maga is intézményi tény, mely intézményi tények mintájára épül fel, de a többi közül kiemeli, hogy létéhez nem szükséges a többi. A többi intézményi tény azonban nem jöhet létre a nyelv szimbolizáló sajátossága nélkül, mely lehetővé teszi, hogy egyes objektumokat a fizikai sajátosságain túlmutató feladattal, státusfunkcióval lássanak el. Az intézményi tények ugyanis általában egyáltalán nem a fizikai sajátosságaik alapján látják el feladatukat. A határok példájánál maradva, az országhatárok is elenyészően kevés esetben "természetes” határok, de az egyes országokon belüli közigazgatási egységek, például a régiók határai szinte kizárólag az ember általi feladatkijelölés alapjăn határozódtak meg. Searle állítása szerint e státusfunkciók tehát csupán a kollektív elfogadás vagy elismerés alapján láthatók el. 
Searle elméletét továbbgondolva helyettesíti Apel a kantiánus tudatot mint az ismeretek érvényességét igazoló végső instanciát az ideális kommunikációs közösség eszméjével (Felkai 2001, 11). Számára az érvelés tekinthető az összes társadalmi intézmény „meta-intézményének”, mely a nyelvvel együitt a kölcsönös megértés transzcendentális feltétele (Apel 1990, 36). Eszerint az igazság kérdéseit nyilvánosan, az egyenlőnek tekintett érdekeltek konszenzusára alapulva kell eldönteni. Bár számos ponton eltér az apeli felfogástól, ez egyúttal a habermasi kommunikatív etika egyik alapgondolata is. Habermas $(1986,188)$ azokat a kisléptékü terekhez köthető kis közösségeket, melyekben lehetöség van a hasonló nézetegyeztetés lefolytatására, az életvilág kontextusának nevezi. Kommunikatív racionalitás (Habermas 1984) alatt pedig olyan kommunikatív gyakorlatot ért, mely során mindenféle érvényességi igény megjelenhet a résztvevők részérỏl, s azok közül a közösség tagjai által interszubjektíven osztott életvilágon alapuló tudás, meggyőzödés mentén kialakított jobb érv kerül elfogadásra. Ez azonban feltételezi az ,ideális beszédhelyzet" meglétét, mely a dialógusban betöltött szerepek elvileg korlátlan felcserélhetőségére épüi; illetve megköveteli, hogy semmilyen külsỏ kényszer ne háborítsa a kooperatív és kizárólag érveken nyugvó közmegegyezés előállításának menetét, semmilyen előfeltevés ne húzhassa ki magát huzamosabb ideig a megmérettetés alól, és hogy bizonyos helyzetekben egyetértésre kell jutni arról, hogy mi számít általános és mi partikuláris érdeknek (Felkai 2001, 22). A diskurzus alatt Habermas tulajdonképpen ezeket a kényszermentes kommunikációs szituációkat érti (Blotevogel 2000, 131). Az ezekben lefolytatott nézetegyeztetések során elfogadott jelentések magától értetőđö, implicit tudássá halmozódnak fel az egyén számára. Ezzel a tudással annyira meghitt viszonyban van, hogy azt meg sem tudja kérdőjelezni. Az életvilág háttérfeltevések olyan, nyelvileg szervezett készlete, amely a kulturális áthagyományozás formájában reprodukálódik (Habermas 1986, 189). Alapvetően ezekben a kisléptékủ terekben újratermelődő tudáskészlet az ott élő közösség tagjai szocializációjának alapja, ebbỏl nyeri az egyén a térre vonatkozó értelmezéseit is (Faragó 2003a, 24). A térkoncepciók egy része hasonló szituációkban született és születik, ahol a beszélők tehát személyesen is kapcsolatot létesítenek egymással, és lehetőség van a jelentés interszubjektív egyeztetésére.

\section{A „készen kapott” térfogalmak igazsága: kontextus és hatalom}

A társadalom tagjai azonban nem vesznek, vehetnek részt egyformán a térstruktúrák megalkotásában: kevesek igazán aktívan, míg a nagy többség csupán passzív fogyasztója annak, illetve a már „kész” fogalmak alapján alakítva mindennapjait azokat újratermeli (Paasi 2001, 13). Searle modellje nem foglalkozik azzal, hogy milyen körülmények között alakul ki a társadalmi tények kollektív elfogadása. Összemosódik nála emellett a kis- és nagyléptékü terekben formálódó konszenzus is, mely által ezek a tények létrejönnek.

Habermas (1984) már egyértelmủ különbséget tesz a kommunikációs rendszerek két ideáltípusa között: a már említett kommunikatív racionalitás az egyik, a másik 
pedig az instrumentális racionalitás. Utóbbi a cselekvés-koordináció egy másik formájához kapcsolódik: a sikerre orientált instrumentális (vagy stratégiainak is nevezett) cselekvés során a beszélő a mondanivalójának érvényességét az igazságra, hatékonyságra vonatkoztatva támasztja alá, a másik személyt pedig befolyásolni akarja, nem érvekkel meggyőzni.

Az igazság kérdésének kapcsán utalhatunk ismét Searle-re, aki elveti, hogy egy tényállás csakis valamilyen fogalmi rendszeren belül létezik. Példáként a következöt hozza: arra a kérdésre, hogy a szobában hány tárgy található, megszámolhatjuk a szoba bútorzatának egyes darabjait. Egy olyan fogalmi rendszer szerint azonban, amely nem tesz különbséget a bútorzat egyes tételei között, hanem az egész berendezést egyetlen egészként kezeli, más választ kapunk erre a kérdésre. A két eltérő mértékrendszer alkalmazásával alternatív, egyformán igaz leírást kapunk a világról. Searle (2000, 32-33) szerint a látszólagos összeférhetetlenség könnyen feloldható annak világossá tételével, hogy melyik válasz melyik számítási rendszer alapján született: „Ha értjük a kijelentések természetét, akkor nincs semmiféle összeférhetetlenség." Searle nem foglalkozik azonban azzal, hogy számtalan esetben a kettő vagy még több fogalmi rendszer közül egy bizonyosat kell alkalmaznunk, s ennek számos következménye van. Vegyük például a magyar régiók kérdését: hány régió van Magyarországon? Mielőtt erre válaszolni próbálunk, tudnunk kell, milyen fogalmi rendszer szerint meghatározott régiókra vonatkozik a kérdés: gazdasági vagy kulturális szempontból erősebb kohéziót felmutató (s magát ezen ismérv alapján megkülönböztetó), tervezési-statisztikai, vagy területfejlesztési régiókra - és még folytathatnánk a sort. Ha csak az utolsó ismérv alapján tesszük fel a kérdést, akkor is pontosításra szorul, hogy az melyik időpontra vonatkozik, hisz az 1999. évi XCII. törvény a területfejlesztés megújításáról módosította a fogalmi rendszert, amelyen belül az megválaszolható. Ahogy Searle is kifejti, a félreértések tisztázhatók, ha világos, melyik fogalmi rendszeren belül keressük a választ. Ennél azonban több a tét, hiszen annak, hogy melyik fogalmi rendszer alkalmazandó, számos folyománya van: a magyar területfejlesztési régióknál maradva gondoljunk csak Zala megye példájára.

A fentiek alapján két, egymással összefüggő kérdést érdemes közelebbről megvizsgálni. Az egyik, hogy egyes szavak, fogalmak - így olyan térkoncepciók is, mint a régió - bizonyos kontextuson belül nyernek jelentést. Ezzel egybecseng a hermeneutika (a megértés művészetének tana) álláspontja, mely szerint egy kijelentést mindig egy nyelvi és az adott történelmi keretben kell értelmeznünk. Gadamert $(1984,192)$ idézve: „... a szöveget mindig a kor, illetve a szerző nyelvhasználatából kell megértenünk." Hiszen, ha a térre vonatkozó fogalmakat, mint például a régiót társadalmi konstrukciónak fogjuk fel, akkor egyúttal történelmi produktumnak is tekinthetjük (Miggelbrink 2002, 46). Másrészt fontos tudni, hogy egy adott, régiókról szóló beszéd, diskurzus esetén a beszélő milyen értelemben használja a régió szót? Ezzel elkerülhető lenne az egymás mellett való elbeszélés is.

A másik felmerülỏ kérdés pedig, hogy egy adott kontextusban miért egy bizonyos értelmezés válik dominánssá. Ha egy adott kontextusban, például az említett 
törvény elfogadása utáni Magyarországon ezt halljuk: területfejlesztési régió, akkor mi az a tényező, ami biztosítja, hogy ugyanarra gondolunk?

E két kérdés kapcsán kínálkozik az alkalom, hogy két, a posztstrukturalista fillozófiák közé sorolt gondolatrendszerre hivatkozzunk. A posztstrukturalista megközelítések az univerzális, transzcendentális a priorit visszautasító episztemológiára épülnek, melyek elutasítják, hogy az egyes kijelentések „,a valóságot” tükrözik. Elvetik a feltételezést, hogy a megfigyelhető valóság rendelkezik egy mögöttes struktúrával; számukra nincsen rögzített pont, transzcendentális horgony, független megkülönböztetés, vagy szükség a metafizikára. A nyelv már nem egy egyedül lehetséges valóságot reprezentál; a „reprezentál” szó annyit tesz, mint a nyelv által, diszkurzíven megalkotni a lehetséges valóságok közül egyet (Zierhofer 2002, 4).

A posztstrukturalisták egyik legtöbbet hivatkozott alakja Derrida, aki Saussure strukturalista jelentéselméletét gondolja tovább. Utóbbi már valamennyire szakít a metafizikai tradícióval, és egy nyelvi jelölő, például egy szó jelentését nem annak pozitív tulajdonságához köti, hanem a többi nyelvi jelölőhöz való viszonyához, azoktól való különbözöségéhez (Krauss 2001, 27). Maga a strukturalizmus elnevezés is onnan ered, hogy a nyelvi jelölők definiáló jegyeit egyedül azoknak az összes többihez való, szisztematikusan rögzített kapcsolata által tartja meghatározottnak (Habermas 1998, 149), vagyis a jelentéselemek kölcsönösen egymásra épülö, statikus struktúrájából származtatja a jelentést. A „régió” szó jelentése is csupán a szó más szavakhoz való viszonya alapján határozható meg, hiszen eleve annak bárminemủ definíciójához más szavakra (például: terület, állam, határ stb.) van szükségünk. Csakhogy nem tekinthetjük állandónak a szavak egymáshoz való viszonyát, különösképpen, amikor folyamatosan új szavak, kifejezések is képződnek (mint például Európai Unió), s ezekkel bővül a jelentéselemek hálózata. Derrida is a jelentésgeneráló különbségek struktúrájának statikus voltára vonatkozó, transzcendentális a priori feltételezést kritizálja, mely csupán a jelenlét egy adott pontját véve megalapozott. Voltaképpen a saussure-i strukturalista modellt dinamizálva vezeti be a posztstrukturalizmust: Derridánál a jelentésgeneráló különbségek sosem véglegesek, hanem állandóan mozgásban vannak. A különbség tehát nem csupán fix különbséget jelent, hanem egyúttal a vég nélküli jelentés-eltolódások dinamikáját (Krauss 2001, 17). Feloldja tehát a rögzített pillanat saussure-i rendezőelvének kiváltságos szerepét; számára (Derrida 1976, 158) „,semmi sem létezik a szövegen kívül”. Megközelítésében értelmetlen a „végső” igazság, a fix jelentés keresése: a jelentések mindig ideiglenesek és az adott kontextustól függenek, az egyes szövegek mindig őket megelőző reinterpretációi (Pratt 1991, 260). A nyelvi kifejezések nála változó kontextus függvényében megváltoztatják jelentésüket, a nyelv sajátossága éppen az, hogy kijelentések egyes kontextusokból átültethetők másikba (bỏvebben lásd: Habermas 1998, 162; Zierhofer 2002).

Igaza van Derridának abban, hogy nincs értelme egy fogalom végső jelentését, igazságát keresnünk. Áll ez a ,zavarba ejtỏen sok értelmet kapott” (Papp-Tóth 1999, 131) régió szó esetére is. Félrevezetỏ lehet azonban, hogy sokszor úgy tünik, megtaláltuk, vagy megtalálták ezt a bizonyos fix, végső jelentést. E ponton hasz- 
nosnak tünik egy másik posztstrukturalista, Foucault említése. A foucault-i álláspont szerint minden létező egy diskurzuson belül nyer jelentést, válik a tudás tárgyává. Nem azt tagadja, hogy a dolgok anyagi mivoltukban vannak jelen (lehetnek jelen) a nem-diszkurzív területen, hanem azt állítja, hogy azok nem létezhetnek, nem jelenhetnek meg egy nem-diszkurzív vákuumban. Saját szavaival (Foucault 1991, 881): „....a diskurzust nem kell feloldani elözetes jelentések terében; ne gondoljuk, hogy a világ olvasható arccal fordul felénk, amelyet csupán meg kell fejtenünk; a világ nem tudatunk cinkosa; a diskurzus előtt nincs prediszkurzív gondviselés, amely a világot kedvünk szerint valóvá alakítaná. A diskurzust olyan erőszakként kell felfognunk, amit a dolgokon követiink el, mint valami általunk a dolgokra eröszakolt gyakorlatot, és a diskurzus eseményei e gyakorlatban találják meg szabályszerüséguik elvét." A térképzetre vonatkoztatva ezt úgy értelmezhetjük, hogy térre nem tekinthetünk úgy, mint egy, a megfigyelötöl függetlenül létező rendezőelvre.

Foucault elöször mint a tudás archeológusa közelített a beszédekhez, vagyis diskurzusokhoz. A tudás nála lehet független a tudománytól, általánosságban diszkurzív gyakorlatok által szabályosan kialakított elemek halmazát érti alatta (2001, 233). Az archeológia pedig nem egy mögöttes beszédet, elrejtőzỏ vagy megnyilvánuló gondolatokat, reprezentációkat, képzeteket kutat fel, hanem a beszédek által múködésbe hozott szabályegyuittest, vagyis a diszkurzív gyakorlatok típusait és szabályait. Célja a beszéd-tárgy módszeres leírása. Azt vizsgálta többek között, hogy a történelem során hogyan jöttek létre a diskurzusok igazságát konstituáló szabályok, mindenekelött a humán tudományok területén. Ahogy A tudás archeológiája (2001, 66-67) címủ müvében megfogalmazza: „A feladat abban áll, hogy a beszédeket - többé már - ne jelek (olyan jelölö elemek, amelyek tartalmakra vagy reprezentációkra utalnak) halmazaiként fogjuk fel, hanem gyakorlatokként, amelyek megadott rendszer szerint alakítják ki a tárgyakat, amelyekröl beszélnek. Természetesen a beszédek jelekből állnak; de több az, amit tesznek, mint jelek felhasználása dolgok jelölésére. Ez a több az, ami lehetetlenné teszi a beszéd puszta viszszavezetését a nyelvre és a kiejtett szóra. Ezt a többet kell megjeleníteni és leírni." A többlet leírása abban ragadható meg, hogy az archeológia megjeleníti a beszédképzödmények és nem-diszkurzív területek (intézmények, politikai események, gazdasági gyakorlatok és folyamatok) közötti kapcsolatokat; de nem az elöbbiek motivációjára kérdez rá, vagy hogy mi fejeződik ki bennük, hanem, hogy az adott kijelentéshalmazra érvényes szabályok milyen kapcsolatban lehetnek nemdiszkurzív rendszerekkel.

Később az általa geneológiainak nevezett történetírásra irányítja figyelmét; ezen belül a történelmet mint diskurzus-univerzumok értelmetlen, kaleidoszkópszerü alakváltozásait fogja fel (Habermas 1998, 228). Azt, hogy miképpen formálódnak a diskurzusok egy adott korban, miért lépnek fel s tünnek el ismét, a hatalommal magyarázza. Egy adott koron belül sem megengedett a diskurzusok korlátlan szaporodása (Foucault 1991, 869): „....minden társadalomban ellenörzik, kiválogatják, megnevezik a diskurzus termelését, majd a termékeket újra elosztják, mégpedig 
bizonyos számú eljárás szerint, melyeknek az a szerepük, hogy csökkentsék a diskurzus veszélyeit..."

A szelekció foucault-i megközelítésben a hatalom mentén történik, a hatalmi viszonyoktól fủgg, hogy mely diskurzus szerzi meg az igazság, az igazságot tủkröző tudás státuszát. Ehhez kapcsolhatjuk válaszunkat arra a korábban feltett kérdésre is, hogy mitől fủgg például, hogy a területfejlesztési régiókról hallva ugyanazokra a lehatárolt teruletegységekre gondolunk. Minden kornak megvoltak (és vannak) azok a tudásrendszerei, amelyek az adott kor emberének gondolkodását, viselkedését befolyásolták, anélkül, hogy annak tudatában lett volna. Foucault (l. Fontana-Pasguino 1980) szerint az igazság olyan rendezett mủveletek rendszere, mely állításokat termel, szabályoz, oszt el, áramoltat és müködtet. Ez kapcsolódik az öt termelö és fenntartó hatalomrendszerekhez, illetve az általa indukált és öt kiterjesztő hatalmi hatásokhoz. Ez az igazságrezsim minden társadalom sajátja. Az igazság csekély számú nagy, domináns, sőt kizárólagos politikai és gazdasági apparátus felügyelete alatt termelödik és kerül továbbításra, és emellett politikai vita és társadalmi konfrontáció tárgya is. Foucault a hatalom természetéröl a következőképp vélekedik: „A hatalom lehetöségfeltételét ... korántsem valamilyen elözetesen adott középpontban, a szuverenitás egyetlen fókuszában kell keresnünk, amelyból a hatalom származékos, vagy lefelé irányuló formái mintegy sugárszerüen áradnak ki; hanem azoknak az erőviszonyoknak az örökösen változó szubsztrátumában, amelyek egyenlötlenségeikkel újra meg újra létrehozzák, gerjesztik a - mindig helyi és mindig ingatag - hatalmi viszonyokat.” Továbbá: „Ne keressünk itt semmiféle vezérkart, amely racionalitását irányítaná; nincs olyan kormányzó kaszt, nincs olyan csoport - ellenörizze bár az állam mechanizmusait, vagy hozza meg akár a legfontosabb gazdasági döntéseket -, amely az adott társadalomban müködő hatalmi hálózat egészét kézben tartaná és müködtetné." (Foucault 1999, 92-94)

A hatalom tehát Foucault szerint alulról jön; a tudás-hatalom helyi, kisléptékủ központjainak (mint a család, kiscsoportok, intézmények) erőviszonyai a tartófelületei a hatalom egész társadalomra jellemző tagolódásának. Egy diskurzus kimondhatósága, $\mathrm{s}$ fớleg általános igazsággá válása elválaszthatatlan a hatalmi viszonyoktól: azok egyes diskurzusformákat preferálnak (Ocskay 2002), másokat pedig marginalizálnak.

Azonban legtöbbször az egymással szembehelyezkedő szereplők diskurzusai ugyanazzal a szókészlettel, ugyanazokkal a kategóriákkal dolgoznak (Foucault 1999, 100-102): „,...nem úgy kell elképzelnünk a diskurzus világát, mintha azt két részre osztaná az elfogadott és kirekesztett, illetve a domináns és az elnyomott nyelvi közlés; a diskurzus világát a különféle stratégiákban szerepet játszó diszkurzív elemek sokféleségének kell tekintenünk. ... Nem úgy kell elképzelni a dolgot, hogy az egyik oldalon áll a hatalom diskurzusa, a másik oldalon pedig a másik, vele szemben álló. A diskurzusok voltaképpen taktikai elemek vagy tömbök az erőviszonyok mezejében; mindamellett igen különbőzőek, sőt egymásnak ellentmondóak is lehetnek egyazon stratégián belull; még az ellentétes stratégiákba is átkerülhetnek, s ehhez még formájukat sem kell megváltoztatniuk." 
Bár a hatalom Foucault által középpontba állított mikrofizikai vetülete kétségtelenül fontos, $s$ egyetérthetünk azzal is, hogy a hatalmat számtalan pontból kiindulva lehet gyakorolni, mégis a fentieket továbbgondolva szükségesnek tartom feltételezni, hogy a helyi kontextusok hatalmi viszonyai hatalmi csomópontokat hoznak létre. $\mathrm{S}$ ha az ezekben fellelhető szereplök váltakoznak is, maguk a csomópontok, mint például a nemzeti politikaformálásé, tartósan megmaradnak. Emellett a foucault-i nézőponttal szembehelyezkedve úgy gondoljuk továbbá, hogy ezekben kialakul egy domináns diskurzus, mégpedig diszkurzív elemek egy bizonyos kombinációja. Igaz, ezek közül számtalan felbukkan más diskurzusokban is: a magyar regionalizálás kapcsán ilyen, egymással szembehelyezkedő diskurzusokban is megjelenő elemek például a közigazgatási modernizáció, az európai uniós csatlakozásból eredő elvárások, a gazdasági versenyképesség fokozása, a szubszidiaritás elve stb. A domináns diskurzus is ezekből építkezik, de képes magát mint az igazságot, tudást prezentálni, s saját fennmaradását azáltal biztosítani, hogy behatárolja a gondolat és cselekvés számára a „lehetségest".

\section{Totalizáló igény, ủjratermelés és ellenállás}

Miggelbrink (2002) szerint a térbeliségre egyrészt mint valamilyen materiális jellegủ elrendezésre, másrészt kommunikatív úton létrehozott rendre, elrendezésre tekinthetünk. E kettö persze nem független egymástól; a terek és a helyek nemcsak anyagi mivoltukban léteznek és termelödnek újjá, hanem egyúttal diszkurzív képződmények is, s e kêt „képzési-képződési mód” kölcsönösen hat egymásra (AllenMassey-Cochrane 1998, 9-13). E cikk mindenekelött a diszkurzív oldalra helyezi a hangsúlyt, vagyis arra, hogy a térhez, annak egyes elemeihez és viszonyaikhoz az ember bizonyos jelentéseket társít, $\mathrm{s}$ azok így töltik be az észlelés és közlés eszközének szerepét. A térröl való kommunikáció a társadalmi valóság rendezöelve. Akárcsak az életvilág keretei között, azon túlmenöen is a térre vonatkozó fogalmak a kommunikáció eszközei, bizonyos szituációban, bizonyos céllal születnek. A célt követő tevékenység Habermasnál $(1986,197)$ is éppúgy alkotóelemét képezi a kölcsönös megértésre, mint a sikerre irányuló cselekvésnek. A személyes kapcsolatok által behatárolt kisléptékủ terekben van mód, hogy a kommunikációban résztvevők rákérdezzenek az egymás által magától értetődőként használt térfogalmakra, - melyek legtöbbször tudatosan, vagy tudattalanul, de leegyszerüsítök.

Napjainkban azonban, Jessop (2000) megfogalmazásával élve, a diszkurzív módon képzett és intézményei által anyagi létet öltỏ térbeli szintek (scales) megsokszorozódásának lehetünk a tanúi, melyek inkább fokozottan komplex hierarchiákba tagozódnak, mintsem egyszerủen egymásba ágyazottak. Ezek az új térkoncepciók (itt gondolhatunk eurorégiókra, vagy éppen a hazai kistérségi társulásokra) már csak a legritkább esetben gyökereznek a kisléptékủ terekhez köthető kommunikációban. Eltolódás figyelhetỏ meg az egyes terek és helyek nevében a politikai színtéren fellépő és beszélö szereplök javára, illetve, ahogy Paasi $(2001,13)$ megjegyzi, az üzleti szféra és a média szereplöi, tanárok, sỏt a kutatók is fontos pozícióval 
bírnak a térhez kapcsolódó jelentéstartalmak formálásában. A sokasodó, nem interszubjektíven kialakított térkoncepciók a kommunikatív mindennapi gyakorlatban kialakítottakkal megegyeznek abban, hogy szintén egy rejtett a priori térszemléletre épullnek, melynek alapja a tér tartályként való felfogása. Különbség azonban több ponton mutatkozik: egyrészt abban, hogy bizonyos határokon belül ugyan, de egyre inkább totalizáló igénnyel lépnek fel, másrészt esetükben nem biztosított a mögöttes a priori feltételezésekre való rákérdezés lehetősége. A totalizáló igény mindenekelőtt a modern állam részéről jelentkezik, mely a társadalomról szóló tudás termelésének fontos és elsődleges pólusává vált a térbeliség vonatkozásában is, emellett pedig rendelkezik azon mechanizmusok felett, amelyekkel az általa képviselt igazságnak érvényt szerez. Legkézenfekvőbb példa egy törvény elfogadása a parlamentben a régiókról, azok lehatárolásáról, amely a searle-i értelemben performativ kijelentés, és így a világ megváltoztatott reprezentációjával hoz létre változást a világban. Ma már emellett nem elhanyagolandó érvényességi igények jelennek meg a nemzetállamon kívülről: Magyarország vonatkozásában mindenekelött az Európai Unió „nőtte ki magát” észrevehetően jelentős diskurzus-forrássá, már jóval a csatlakozás elött.

A totalizáló igények tehát legtöbbször sikeresen alakítják a valóságot. Ahogy már volt róla szó, a többség csupán passzív fogyasztója ennek, és a már „,kész” fogalmak alapján alakítva mindennapjait azokat újratermeli (Paasi 2001, 13). Újratermeli ezt a média, például, amikor regionális, információs és közéleti lapot jelentet meg egy régió nevével, emblémájával, de a tudományos szféra is, amikor a „már adott” regionális kereteket veszi alapul a vizsgálódásai során, mondjuk egy régió versenyképességének elemzésekor. Sokszor kényszerü ez az alkalmazkodás, hiszen a statisztikai adatok (amelyek másrészt a modern állam „térkezeléséhez” kapcsolhatók) is csupán e séma alapján hozzáférhetők.

Lényeges hangsúlyozni, hogy a diszkurzív módon képzett terek ellenállást is kiválthatnak, ami nem feltétlenül egy ellen-diskurzusban ölt testet, hanem sokszor csak a mindennapi gyakorlatok annak ellentmondó voltában (Häkli 1998, 338). Habermasnál $(1986,197)$ magyarázatot is találunk: „A tradíciók elsajátítása, a szolidaritások megújítása, az egyének társadalmasítása azonban rászorul a köznapi kommunikáció természetadta hermeneutikájára, s ezzel a konszenzusképzés közegére. Az az interakció, amely során az egyik fél a másikat a befolyásolás objektumaként kezeli, elmegy a nyelvileg megteremtett interszubjektivitás eme dimenziója mellett. A kölcsönös befolyásolás keretében nem lehet áthagyományozni a kulturális tartalmakat, nem lehet integrálni a társadalmi csoportokat, s nem lehet szocializálni a felnövekvőket." A hazai regionalizációra e gondolatok úgy alkalmazhatók az olvasatunkban, hogy az egyének nem szoríthatók régiós határok közé, anélkül, hogy megértenék, átéreznék ennek jelentőségét. Illetve szoríthatók, de amíg ez valamiképp nem hatja át mindennapi térkezelésüket, nem lehet csodálkozni azon, hogy például a mai területfejlesztési-statisztikai régiók miért nem rendelkeznek identitással. A régiókban való gondolkodás ettöl függetlenül tetten érhetö, még ha ez nem is a „régió" szó explicit használatával manifesztálódik. Ennek egyik meg- 
nyilvánulási példája, amikor valaki ,alföldi”-ként mutatkozik be. A (magyarországi) köznapi kommunikációban magyarázat nélkül értjük, mit akar ezzel mondani: az e kifejezésben rejlö megkülönböztetéshez a távoli múltban történt a jelentés társítása, az valószínủ szemtől-szembeni kommunikációban gyökerezik, s egyre szélesebb körủ elfogadottsága révén tartalma, ti. hogy az illető valahonnan a Magyarország délkeleti felét ,jelentő" sík vidékről származik, máig áthagyományozódott. Mindamellett a térröl való köznapi beszédben nem merül fel az „Alföld” egzakt lehatárolásának kérdése, ha valaki alföldinek vallja magát, nem kérdezünk rá, hogy valóban az Alföld része-e az adott település. E kijelentése alapján inkább a térhez való viszonyát, térhasználatát illetően tudunk meg valamit: nem szokott a dombok-hegyek látványához, az ilyen terepen való közlekedéshez stb. Nem így van ez a megyék esetében, amelyek mint a települési és országos szint között lévő egységek, szintén régiók: az ő esetükben az egyén számára adott a határ, mely alapján azt értelmezi. Bár e régiók azonosítása is a téregységek megkülönböztetésének szükségességéböl ered, de ez a szükségesség nem a szemtől-szembe kommunikációban, hanem az állam szintjén jelentkezett. Utóbbi rendező igényével karöltve egyúttal a lehatárolás is szükségszerủ volt. A megye hosszú múltja, az egyén életét átszövö volta miatt mégis képessé vált arra, hogy a térbeli szocializáció fontos eleme legyen. A kölcsönös, illetve ez esetben felülről érkező befolyásolás is eredményezheti tehát a jelentéstartalmak áthagyományozását, de ehhez mindenképpen idő és a mindennapi térbeli gyakorlatokhoz való szoros kapcsolódás kell.

A „készen kapott” térkoncepciók ellen a tudomány berkeiben is kialakulhat paszszív vagy aktív ellenállás. Utóbbit Miggelbrink $(2002,167)$ nyomán emancipatórikus töltetủnek nevezhetjük, mely elveti a tér domináns reprezentációinak létjogosultságát, s ehelyett azt hangsúlyozza, hogy a térrel kapcsolatos elbeszéléseknek, lokális diskurzusoknak a sokasága van jelen. Célja a már-már készpénznek vett térfogalmak dekonstruálása, demisztifikálása. Ez posztpozitivista színezetủ beállítódást feltételez, melyből következik, hogy az erre az álláspontra helyezkedő sem állíthatja nézőpontja abszolút objektivitását és semlegességét. A hangsúly azon van, hogy a különbözö szereplök megnyilvánulásainak diszkurzív beágyazottságára saját értékválasztásainak explicitté tétele mellett világít rá, s így nyíltan vállalja, hogy saját kijelentései is egy diskurzuson belül léteznek.

\section{A diszkurzív megközelítés elméleti alapjai: megengedhetö-e az eklekticizmus?}

A cikkben hivatkozott filozófiai gondolatrendszerek összekapcsolásának helyessége valószínüleg sokak számára kérdéses, hiszen egy filozófiai életmủ kellően átfogó és igazán mély ismeretét kevesek mondhatják magukénak, $\mathrm{s}$ akkor még mindig ott van annak interpretációs problémája, illetve több gondolatrendszerrel való munka esetén azok „kompatibilitásának”, fogalmi átfedéseinek kérdése, vagyis, hogy egyáltalán megengedhető-e azokból valamiféle eklektikus modell megalkotásạ. Az e tanulmányban szereplök közül klasszikus példának számít Searle és 
Derrida vitája (bövebben lásd: Habermas 1998, 160-165; Zierhofer 2002, 11), illetve a habermasi kommunikatív etika és a foucault-i hatalomelmélet összekapcsolási nehézsége (Faragó 2001, 21). Az ellentétes álláspontok kimerítö ismertetése nem lehet e cikk feladata, ehelyütt csupán a habermasi és foucault-i gondolatkör „ütköztetéséröl” lesz szó. Richardson (1996, 280) szerint ezek, illetve az ezekre építők egyenesen két, jól elkülönülő táborba sorolandók. A következökben röviden arra szeretnék rámutatni, hogy miért leegyszerüsítő, sőt, bizonyos szempontból értelmetlen ez a szétválasztás, $\mathrm{s}$ miért tartjuk lehetségesnek és hasznosnak is egyidejü felhasználásukat, többek között a régió-kialakítás kérdése kapcsán is.

A modernséget csupán befejezetlen projektnek feltételező habermasi gondolatkör és benne a kommunikatív racionalitás mindenekelött azért vonzó sokak számára, mert így nem kell feladnunk az észre való hivatkozást, hanem a társadalmi diskurzusokban megnyilvánuló relatív racionalitásra támaszkodhatunk. Így lehetőség van az ész „megtartására”, az interszubjektív kommunikáción belüli érvelés segítségével (Healey 1993, 237; Blotevogel 2000, 133). Mintegy menedéket kínál ez a nézöpont azoknak, akik számára a modernséget meghaladni kívánók (vagy ha úgy tetszik, ,posztmodernek”) relativizmusa diszkomfortot okoz (Throgmorton 1991; Blotevogel 2000). Ahogy Blotevogel $(2000,129)$ megjegyzi, az, hogy a posztmodern megközelítésben az igazság helyébe a diskurzus lép, $\mathrm{s}$ nincsenek metakritériumok, amelyek alapján választhatunk az egymással versengő, érvényességre jogot formáló kijelentések közül, végül az érvek reménytelen relativizációját eredményezi. Osztjuk véleményét, miszerint az értelem, a racionalitás elvetése helyett a társadalmi diskurzusok relatív racionalitására kell támaszkodnunk, $\mathrm{s}$ hogy ezek között kell konszenzust keresni. E habermasi ihletésủ nézőpontot a régiók létrehozására szigorúan véve úgy adaptálhatjuk, hogy feltételezzük egy kommunikációs közösség létét, mẹlyet az érintettek, vagyis ez esetben a „regionalizálandó” állam polgárainak összessége alkot, akik érveik jătékszabályokhoz kötött cseréje révén állapodnak meg a régió mibenlétében. Ily módon a „régió” szó jelentése, s egyúttal a régió(k) esetleges határa, szerepe stb. interszubjektiven osztott. E diskurzus lefolytatása azonban idealista ábrándnak tünik, $\mathrm{s}$ a habermasi kommunikatív etikával, illetve a habermasi megközelítésre épúlö egyéb elméletekkel szemben éppen azok idealisztikus feltételezései kapcsán fogalmazódott meg számos ellenvetés az elmúlt évtizedben (bővebben lásd Störig 1997, 564-566; Faragó 2001, 18; Felkai 2001, 32-42). A régiókról való diskurzus kapcsán sem feltételezhetjük, hogy technikailag, illetve adott idő- és anyagi korlátokon belül megoldható minden érintett bevonása, akik egyébként sem rendelkeznek azonos szintü ismeretekkel és fogalmazási képességekkel, ráadásul nem egy esetben alárendeltek egymásnak. A habermasi modell kritikusai által megfogalmazott ellenvetések is szinte kizárólag az ideális beszédhelyzet létrehozásával szembeni szkepticizmusra vezethetök vissza. Blotevogel $(2000,133)$ szerint azonban a társadalmi diskurzusok erejébe vetett hit nem összekeverendő a naivitással. Ahhoz, hogy megakadályozzuk, hogy ezek kölcsönhatása hatalmi játékokká degradálódjon, Blotevogel szerint az államnak kell világos és kötelező érvényü szabályrendszert kialakítania és felügyelnie. Ennek 
azonban véleményünk szerint nincs és nem lehet meg az intézményi realitása, hiszen az állam maga is a hatalom egyik csomópontjában áll, s nem csupán semleges felügyeleti szerepet játszik. A régió-kialakítás kapcsán is számtalan érvényességi igény jelenik meg különböző szereplők részérỏl a régiók szerepére, határaira stb. vonatkozólag. Általánosan, és így a magyar régiók esetében sem léteznek abszolút érvényességủ metakritériumok, amelyek mentén azok létrehozhatók. Még a gyakran hivatkozási alapként feltünő Európai Unió sem rendelkezik egyértelmü régiómodellel (Grabbe 2001, 1019). A régió-vitában, amelyben tehát különböző szereplök érvei ütköznek, az állam korántsem tekinthetö a kommunikatívan strukturált eszme-csere letéteményesének, hiszen annak ő is résztvevője, s hozzá kötődik a domináns diskurzus. Sőt, mi több, főszerepet játszik a játékszabályok kialakításában, melyek között a különbözö diskurzusok színre léphetnek: a régióknál maradva azok lehatárolásával, a velük kapcsolatban felállítandó intézmények (azok összetételének) meghatározásával egyứttal kijelöli a régiókkal kapcsolatos beszéd tereit, résztvevőit, tárgyait, s ezzel irányadó a régióhoz társított jelentés formálásában.

Ahogy arról már volt szó, a jelentésnek sosem lesz végső formája; a régió különbözö kontextusban más-más értelmet nyerhet, különböző diszkurzív pozíciókból más-más jelentéstartalommal is feltölthető. A Habermast követőket és bírálókat láthatólag az osztja meg, hogy egy adott kontextusbeli jelentés kialakítását lehetségesnek tartják-e, akárcsak megközelítöleg is, a habermasi elveknek megfelelően (mely jelentés következésképpen interszubjektíven osztott), vagy nem (ekkor a jelentés inkább felülröl oktrojált). Egyértelmüen az utóbbiak közé tartozik Richardson (1996), aki az érvelés keretei idealisztikus modelljének tartja és egyenesen "hatalomvak"-nak bélyegzi a habermasi megközelítést, mely figyelmen kívül hagyja, hogy a versengő diskurzusoknak mind megvan a sajátos tudás-hatalom dinamikájuk. Inkább a foucault-i nézőpontot preferálja, melyböl lehetöség nyílik megfigyelni, hogy egyes érvek hogyan válnak tudássá. Hasonlóképp Foucault ,felé húz" Flyvbjerg $(1998,227-228)$ is, aki szerint a racionalitást mindig áthatja a hatalom, ezért félrevezető és értelmetlen olyan racionalitás-fogalommal dolgozni, melyből az hiányzik ${ }^{2}$. Ebben a megközelítésben a régió-kialakítással kapcsolatban megfogalmazott adott érvényességi igény állítólagos ésszerüsége is csupán az azt megfogalmazó szereplő hatalmi érdekei szempontjából ésszerủ. A foucault-i gondolatokkal szimpatizálók szemszögéből tehát nem hihetünk a jelentés interszubjektív kialakulásának lehetőségében, ehelyett a régióhoz való jelentés társítása a hatalom racionalitása mentén megy végbe.

A habermasi kommunikatív etika és a foucault-i hatalomelmélet összekapcsolási nehézségei véleményünk szerint mindenekelőtt abból adódnak, hogy a két elmélet eltérő gondolati síkon operál. Ezért talán nincs is értelme a kérdésnek, hogy melyik nézőpont elfogadhatóbb. Fontos kiemelni, hogy Habermas (1984) tulajdonképpen elébe megy a modelljét ért vádaknak, amikor maga is elismeri, hogy a kommunikatívan strukturált kapcsolatok egyre inkább marginalizálódtak, mivel hiányoznak azok az intézmények, amelyek megvédenék a magán- és közszférát a gazdasági és közigazgatási alrendszerek dinamikájával szemben. A modernitással szembeni 
Tér és Társadalom 18. évf. 2004/1. 73-91. p.

elégedetlenség álláspontja szerint abban gyökerezik, hogy nem sikerül intézményesíteni az értelem különbözö dimenzióit kiegyensúlyozott módon. Bár a habermasi modell megvalósításának társadalmi-politikai lehetőségfeltételei igen szükösek, azok Habermas szemében valójában nem preskriptív koncepciók, hanem racionális anticipációk. Álláspontja szerint a nyelvileg közvetített emberi kommunikáció mélyszerkezetében bizonyos normatív anticipációk húzódnak meg és magában a nyelvben gyökerezik az általános és korlátozatlan konszenzus (a valódi konszenzus) iránti immanens igény (lásd Felkai 2001, 20;35). Az ideális kommunikációs közösség tehát nagyon kisszámú esetben áll rendelkezésünkre, de még azokban az esetekben is, amikor az ideális beszédhelyzet feltételei nem teljesülnek maradéktalanul, a résztvevőkben él annak hipotézise, $s$ annak megfelelően vesznek részt a vitában. A magyarországi régió-vitában is megfogalmazódnak kritikus álláspontok, $\mathrm{s}$ ezek képviselöi, még ha tudatában is vannak csekély befolyásuknak, mégis azt feltételezik, hogy érveikkel valamiképp az általuk helyesnek vélt irányba terelhetik a régió-kialakítás folyamatát, ellenkezó esetben értelmetlen lenne megnyilvánulniuk. A habermasi diszkurzusetika feltevései tehát a résztvevők (valójában később csupán részben beteljesülö) elöfeltevéseinek tekinthetők, illetve olyan utópisztikus konvenciórendszernek, melynek akár csak a megközelítőleges megvalósítására való törekvés a jövőbeli békés emberi együttélés szempontjából mindenképpen kívánatos. Úgy vélem, hogy a megvalósításra való törekvésben hasznos lehet a foucault-i gondolatrendszer néhány eleméhez, megfigyeléséhez folyamodni. Hiszen a habermasi elképzelés többek között ott nem felel meg a valóságnak, hogy minden érintett részt vehet az adott vitában, mindenki ki tudja fejteni a véleményét, meg tudja fogalmazni az érveit (Faragó 2001, 18). A foucault-i genealógia pedig éppen azokra a tudásokra irányítja figyelmét, amelyeket diszkvalifikálnak, „mert nem tárgyszerü, vagy, mert nem eléggé kimunkált: naiv, a hierarchia alsó részén, a megkövetelt tudás- és tudományosság-színvonal alatt elhelyezkedő" tudásfajtákról van szó (idézi Habermas 1998, 230). A modern állam által képviselt, térrel kapcsolatos tudás (is) technokrata szemléletủ és szabványosított nyelvezetü. Ezzel szemben más tudásfajták, például implicit, látens térképzetek (mint az említett, az Alfölddel kapcsolatos régióképzet) birtokosai már csak azért sem tudnak megnyilvánulni, mert hỉján vannak a képességnek, hogy tapasztalataikat kifejezzék, ráadásul az eleve adott koncepcionális keretek között. Foucault stratégiája a régió-kialakítás kapcsán az olvasatunkban az lenne, hogy feltárja azokat a térrel kapcsolatos lokális, marginális és alternatív tudásokat, amelyek önnön erejukből nem tudnak hivatalos tudássá emelkedni ${ }^{3}$.

Úgy gondoljuk, hogy a kétségtelen különbségek ellenére hasonló feltételezések és megfontolások húzódnak meg a habermasi és foucault-i tábor gondolatai mögött, és ezek a diskurzusok dekonstruálására tett kísérletnek egyulttesen képezhetik az alapját, akár a régiókról szóló diskurzusok esetében is. Mindenekelőtt abban értenek egyet $-\mathrm{s}$ erre a közös kiindulópontra épít ez a cikk is -, hogy a nyelv segítségével csupán a valóság egy lehetséges változatát hozzuk létre. Ahogy Zierhofer találóan megjegyzi $(2002,4)$, Habermas munkásságának ez a ,posztmodernisztikus” oldala. A különbségek tekintetében, ti. hogy elfogadjuk-e transzcendentális a priori vagy 
más univerzális érvényességi igények létét, e cikk a habermasi oldalra helyezkedik, mely szerint léteznek ilyẻnek, mint például kultúra, természet, emberségesség. Ezek, ismét Zierhoferre utalva, Habermas gondolatkörében a modernizmus maradványai. A posztstrukturalisták, mint Foucault, ezeket el nem utasítják, hiszen egy ilyen abszolút (ez esetben negatív) érvényességi igénnyel önmaguknak mondanának ellent, de nem is fogadják el (Zierhofer 2002, 4). Éppen ez vezet a végletes relativizmushoz, melynek kritikájára már utaltunk.

\section{Összegzés: a diszkurziv megközelítés jelentösége}

E tanulmány mindenekelött azon a meggyöződésen alapult, hogy a nyelv nem a külső, a nyelven kívüli valóságról tesz kijelentés(eke)t, úgymond „objektíven” tükrözve azt, hanem, hogy a kijelentések egyúttal a valóság létrehozásában is szerepet játszanak. A térbeliséggel kapcsolatos fogalmak sem a tér eleve létező leképezései, hanem kommunikációs folyamatok eredményei. A régió mint entitás is mindig egy adott kommunikatív megkülönböztetésből adódóan vălik entitássá, $\mathrm{s}$ a kontextusok sokasága, melyen belül megkülönböztetéseket eszközölhetünk, magyarázza a szó jelentéstartalmainak sokszínüségét. A tér reprezentációjában különböző tudást és valóságot megjelenítő, racionalitásokat kifejező diskurzusok küzdenek egymással a hegemónia megszerzésére. A küzdelem azonban kiegyenlítetlen; a hatalom egyes diskurzusokat (a régiók esetére lefordítva: bizonyos ismérvek mentén képzett entitásokat) preferál, s mindig maradnak elnyomott nézöpontok. Ahogy Häkli (1998) megjegyzi, a tudás mindig egy bizonyos álláspontot képvisel, amely a társadalmi élet (social world) egyes vonásait kiemeli, s másokat elhomályosít. Flyvbjerg (1998) megfogalmazásában a hatalomgyakorlás legfőbb eszköze az, hogy meghatározza a valóságot a racionalitás meghatározásával. Ez utóbbiról azonban a racionálisnak tünő érvrendszer szétbontásával legtöbbször kiderưll, hogy csupán racionalizáció.

A diszkurziv megközelítés aktualitását többek között az adja, hogy a magyar teruleti szintek terén a közelmúltban jelentős változások mentek végbe, illetve még továbbiak várhatók, $\mathrm{s}$ a térstruktúra átrajzolásával egyben új érdek- és diskurzusterek (Faragó 2003a, 29) is létrejönnek. A térröl, és ezen belül a régiókról mind a köznapi, mind a politikai és tudományos beszéd is egyre jobban kibontakozóban van. E cikk szándéka szerint azoknak kívánt muníciót szolgáltatni, akik a térröl szóló diskurzusok pluralizmusa mellett kötelezik el magukat, de elutasítják a nihilizmusba torkolló relativista álláspontot is. Az elrejtett nézöpontok feltérképezése mellett a térrel (és a régiókkal) kapcsolatos meddỏ viták is áttekinthetöbbek és nagyobb eséllyel megoldhatók, ha a szubsztanciális térontológiákat megkérdőjelezzük és dekonstruáljuk.

\section{Jegyzetek}

${ }^{1}$ A szerző kơszoonnetét fejezi ki Faragó Lászlónak a cikk megírása során adott hasznos tanácsaiért.

${ }^{2}$ Mások, mint Zierhofer $(2002,12)$ elutasítják a habermasi megkỏzelités állitólagos hatalomvakságára vonatkozó kritikát, mondván az érvelés, amely Habermasnál $(1984,18)$ olyan beszédtípus, melyben a 
résztvevớk vitatott érvényességi igényeket tematizálnak, és azokat megpróbáljấk érvényesíteni, illetve kritizálni, reprodukálja mindazon eröket, amelyek nem közvetlenul eröszakon alapulnak.

${ }^{3}$

Fontos ismét megjegyezni, hogy a térrel kapcsolatos tudás bizonyos szempontból veszített nemzetállam-kơzpontúságából, s ennek egyik legkézenfekvőbb példája az Európai Unió terủletpolitikájånak hatása a nemzetállami térfogalom-alkotásra, térrel kapcsolatos gyakorlatokra. Érdekes ellentét feszúl a szubszidiaritás uniós, terulletpolitikában is érvényesítendő alapelve kőzởtt, illetve az uniós teruletpolitikában is megnyilvánuló, totalizáló fogalomalkotás között. Az utóbbi célja egy olyan fơldrajzi tudás létrehozása, amely az uniós tér, terulet és azzal összefüggó folyamatok, jelenségek, problémák közös(ségi) értelmezésén, felfogásán alapul (Scott 2002, 147). Az ellentét abból adódik, hogy míg egyrészt a szubszidiaritás elve a szubnacionális teruleti szintek nagyobb kompetenciakörrel való felruházását szorgalmazza, vagyis célja, hogy lokális diskurzusokat (értsd: szubnacionális teruleti szereplök nézópontját, térfelfogását) hozzon müködésbe (lásd Ocskay 2002), addig ezen szereplớk gondolkodására az uniós fogalomrendszer mintegy koncepcionális keretként nehezedik, vagyis saját megnyilvănulásaikban kénytelenek az Unió adta szókészlettel, fogalomrendszerrel operálni. A kérdéseket illetően, hogy az Európai Unió a térrel kapcsolatos lokális, marginális és alternatív tudásoknak valóban számottevő́n nagyobb "teret" biztosít-e a megnyilvánuláshoz, vagy ez esetben is helye lenne a foucault-i feltáró munkának, inkább az utóbbira adnánk igenlö választ.

\section{Irodalom}

Allen, J.-Massey, D.B.-Cochrane, A. (1998) Rethinking the Region. Routledge, London.

Apel, K-O. (1990) Diskurs und Verantwortung. Suhrkampf, Frankfurt a. M.

Blotevogel, H. (2000) Rationality and Discourse in (Post)modern Spatial Planning, - Salet, W.-Faludi, A. (eds.) The Revival of Strategic Spatial Planning. Royal Netherlands Academy of Arts and Sciences, Amsterdam. 121-134. o.

Curry, M.R. (1996) On Space and Social Practice in Contemporary Geography. - Earle, C.Mathewson, K.-Kenzer, M.S. (eds.) Concepts in Human Geography. Rowman and Littlefield, New York. 3-32. o.

Derrida, J. (1976) Of Grammatology. Johns Hopkins University Press, Baltimore.

Faragó L. (2001) Szeletek a tervezés mélyrétegeiböl. - Tér és Társadalom. 3-4. 11-24. o.

Faragó L. (2003a) A tér kép egy olvasata és a „terulleti” tervezés. - Tér és Társadalom. 1. 19-40. o.

Faragó L. (2003b) A koncepcióvezérelt tervezés általános elmélete. PhD értekezés. Pécsi Tudományegyetem, Pécs.

Felkai G. (2001) Előszó: A diszkurzusetika és a demokratikus politikaj eljărások eszménye. - Habermas, J. A kommunikattv etika. Új mandátum, Budapest. 7-56. o.

Flyvbjerg, B. (1998) Rationality and power. Democracy in power. The University of Chicago Press, Chicago-London.

Fontana, A.-Pasquino, P. (1980) "Truth and power". Interjú Foucault-val. - Gordon, C. (ed.) Power/Knowledge. Selected Interviews and Other Writings. Pantheon Books, New York. 109-133. 0.

Foucault, M. (1991) A diskurzus rendje. - Holmi. 7. 868-889. o.

Foucault, M. (1999) A szexualitás története l. Atlantisz, Budapest.

Foucault, M. (2000) A szavak és a dolgok. Osiris, Budapest.

Foucault, M. (2001) A tudás archeologiaja. Atlantisz, Budapest.

Furst, M. (1993) Bevezetés a filozófiába. Ikon Kiadó, Budapest.

Gadamer, H-G. (1984) lgazság és módszer. Gondolat, Budapest.

Grabbe, H. (2001) How does Europeanization affect CEE governance? Conditionality, diffusion and diversity, - Journal of European Public Policy. 6. 1013-1031. o.

Habermas, J. (1984) The Theory of Communicative Action. Voll: Reason and the Rationalization of Society. Polity Press, Cambridge.

Habermas, J. (1986) Magyarázatok a kommunikatív cselekvés fogalmához. - Magyar Filozófiai Szemle. 1-2. 175-200. 0 .

Habermas, J. (1998) Filozófiai diskurzus a modernségröl. Helikon Kiadó, Budapest.

Hajer, M. (2000) Transpational Networks as Transnational Policy discourse: Some observations on the Politics of Spatial Development in Europe. - Salet, W.-Faludi, A. (eds.) The Revival of Strategic Spatial Planning. Royal Netherlands Academy of Arts and Sciences, Amsterdam. 135-142. o. 
Healey, P. (1993) Planning Through Debate: The Communicative Turn in Planning Theory. - Fischer, F. -Forester, J.(eds.) The argumentative turn in policy analysis and planning. Duke University Press, Durham. 233-253. o.

Hakli, J. (1998) Discourse in the production of political space: decolonizing the symbolism of provinces in Finland. - Political Geography. 3. 331-363. o.

Jessop, B. (2000) The Crisis of the National Spatio-temporal Fix and the Tendential Ecological Dominance of Globalizing Capitalism. - International Journal of Urban and Regional Research. 323-360. o.

Kant, I. (1981) A tiszta ész kritikája. Budapest, Akadémiai Kiadó.

Krauss, D. (2001) Die Politik der Dekonstruktion. Politische und ethische Konzepte im Werk von Jacques Derrida. Campus Verlag, Frankfurt a. M.

Lefebvre, H. (1991) The Production of Space. Blackwell, Oxford.

Miggelbrink, J. (2002) Der gezăhmte Blick. Beiträge zur regionalen Geographie. 55. Institut für Länderkunde, Leipzig.

Ocskay Gy. (2002) A lokális diskurzusok és a globális hatalom - egy hálózatépítési modellprogramról. Tér és Társadalom. 1.17-40. o.

Paasi, A. (2001) Europe as a social progress and discourse. Considerations of place, boundaries and identity. - European Urban and Regional Studies. 1. 7-28, o.

Papp N.-Tóth J. (1999) A regionális fejlödés elméleti kérdései a Kărpát-medencében. - Limes. 3-4. 131-152. o.

Pfeil E. (2003) Önkormányzati integráció és közigazgatás. Dialóg Campus. Budapest-Pécs.

Pratt, A.C. (1991) Discourses of locality. - Environment and Planning A. 23. 257-266. o.

Richardson, T. (1996) Foucauldian Discourse: Power and Truth in Urban and Regional Policy Making.

- European Planning Studies. 3. 279-292. o.

Salet, W.-Faludi, A. (2000) Three Approaches to Strategic Spatial Planning. - Salet, W.-Faludi, A. (eds.) The Revival of Strategic Spatial Planning. Royal Netherlands Academy of Arts and Sciences, Amsterdam. 1-10. o.

Scott, W.S. (2002) A Networked Space of Meaning? Spatial Politics as Geostrategies of European

Integration. - Space and Polity. 2. 147-167. o.

Searle, J.R. (2000) Elme, nyelv és társadalom. Vince Kiadó, Budapest.

Smith, N. (1993) Homeless-global: Scaling places. - Bird, J.-Curtis, B.-Robertson, G.-Tickner, L. (eds.) Mapping the futures: local cultures, global change. Routledge, New York-London. 87-119, o. Störig, H.J.(1997) A filozófia világtörténete. Helikon Kiadó, Budapest.

Throgmorton, J.A. (1991) The rhetorics of policy analysis. - Policy Sciences. 24, 153-179. o.

Weichhart, P. (1999) Die Rüume zwischen den Welten und die Welt der Răume. - Meusburger, P. (ed.) Handlungszentrierte Sozialgeographie. Benno Werlens Entwurf in kritischer Diskussion. Franz Steiner Verlag, Stuttgart. 67-94. o.

Wittgenstein, L. (1989) Logikai-filozofiai értekezés. Akadémiai Kiadó, Budapest.

Wittgenstein, L. (1998) Filozófiai vizsgálódások. Atlantisz, Budapest.

Zierhofer, W. (2002) Speech Acts and Space(s). Language Pragmatics and the Discursive Constitution of the Social. - GAP Working Paper Series. 1. University of Nijmegen, Nijmegen. 1-20. o.

\section{THE REGION AS A DISCURSIVE CONSTRUCT}

\section{KRISZTINA VARRÓ}

By treating concepts of space, such as that of the region as discursive constructs the author attempts to introduce a perspective that seems to be lacking in current accounts about Hungarian regionalisation. The discursive approach rests on the assumption that language is central to our knowledge about reality. On this basis, the emergence and role of spatial concepts is discussed in terms of their ability to coordinate human action. Furthermore, particular attention is paid to those questions that arise in connection with spatial concepts the meaning of which is not rooted in the Habermasian lifeworld and is thus not intersubjectively shared. Emphasis is put on the importance of the discursive context and power and 
possible modes of resistance are equally mentioned. Allusion is made to several strands of philosophical thought, such as poststructuralism and Habermasian action theory. These admittedly diverging accounts agree on looking at entities as discursively constituted and can thus be fruitfully exploited to develop a position, which rejects the taken-for-granted representations of space and aims at their deconstruction. This is hoped to result in uncovering oppressed points of view, as well as in canalizing current debates. 